\title{
Preference for death at home and associated factors among older people in the city of Belo Horizonte, Brazil
}

\author{
Preferência por morrer em casa e fatores associados de pessoas \\ idosas da cidade de Belo Horizonte, Brasil
}

Rafaela Jorge (https://orcid.org/0000-0001-7726-5523) ${ }^{1}$

Natália Calanzani (https://orcid.org/0000-0002-5068-2543) ${ }^{2}$

Adelaide Freitas (https://orcid.org/0000-0002-4685-1615) ${ }^{3}$

Rui Nunes (https://orcid.org/0000-0002-1377-9899) ${ }^{4}$

Liliana Sousa (https://orcid.org/0000-0003-3491-7119) ${ }^{5}$

\footnotetext{
${ }^{1}$ Doctoral Program in Gerontology and Geriatrics, University of Aveiro. Campus Universitário de Santiago. 3810-193 Portugal.rafaelajorge@ outlook.com

${ }^{2}$ Centre for Population

Health Sciences, University of Edinburgh. Edinburgh

United Kingdom.

${ }^{3}$ Center for Research

\& Development in Mathematics and

Applications, Department of Mathematics, University

of Aveiro. Aveiro Portugal.

${ }^{4}$ Faculty of Medicine,

University of Porto. Porto

Portugal.

${ }^{5}$ Department of Education

and Psychology, University

of Aveiro. Aveiro Portugal.
}

\begin{abstract}
We examined people's preferences for place of death and identified factors associated with a home death preference. We asked a representative sample $(N=400)$ of older people $(\geq$ 60 years) residents in the city of Belo Horizonte, about their preferences for place of death in a situation of serious illness with less than a year to live. Data were analyzed using binomial regression to identify associated factors. $52.2 \%$ indicate home as the preferred place of death. Five variables were associated with preference for death at home: those living with 1 child (odds ratio (OR)0.41; 95\% confidence interval (CI):0.180.92; ref: without children); being in education for up to 4 years (OR0.42; 95\% CI:0.20-0.89; ref: higher education); finding it difficult to live with the present income (OR3.18; 95\% CI:1.53-6.62; ref: living comfortably); self-assessed fair overall health (OR2.07; 95\% CI:1.06-4.03; ref: very good health) and selecting "choosing who makes decisions about your care" as the care priority that would matter to them the most (OR2.43; 95\%CI:1.34-4.40; ref: dying in the place you want). Most respondents chose home as preferred place of death. However, most residents of Belo Horizonte die in hospitals, suggesting that preferences are not being considered.
\end{abstract}

Key words Aged, Palliative care, Place of death, Brazil
Resumo Examinamos as preferências das pessoas para o local da morte e identificamos os fatores associados com a preferência pela morte em casa. Perguntamos para uma amostra representativa $(N=400)$ de pessoas idosas ( $\geq 60$ anos) residentes da cidade de Belo Horizonte, sobre suas preferências pelo local da morte numa situação de doença grave, com menos de um ano de vida. Os dados foram analisados utilizando regressão binomial para identificar os fatores associados. Indicaram a casa como o local preferido de morte, 52,2\%. Cinco variáveis foram associadas à preferência por morte em casa: aqueles que vivem com 1 criança (odds ratio(OR)0,41; intervalo de confiança (CI)95\%:0,18-0,92; ref: nenhuma criança); ter até 4 anos de escolaridade (OR0,42; CI95\%:0,200,89; ref: ensino superior); ser difícil viver com o rendimento atual (OR3,18; CI95\%:1,53-6,62; ref: vive confortavelmente); avaliar a sua saúde geral como razoável (OR2,07; CI95\%:1,06-4,03; ref: saúde muito boa) e selecionar "escolher quem toma decisões sobre os cuidados" como a prioridade de cuidado mais importante (OR2,43; CI95\%:1,34-4,40; ref: morrer no local que se quer). A maioria dos entrevistados expressaram preferência por morrer em casa. No entanto, a maioria dos residentes de Belo Horizonte morre nos hospitais, sugerindo que as preferências não estão sendo consideradas.

Palavras-chave Idoso, Cuidados paliativos, Local de morte, Brasil 


\section{Introduction}

Population aging is a worldwide phenomenon ${ }^{1}$. Brazil follows this trend; it is estimated that between 2011 and 2036 it will cease to be a "young country" (up to $7 \%$ of older people) and will become a country with an aged population (more than $14 \%$ of older people $)^{2}$. Due to increasing life expectancy, deaths are more likely to occur among older age groups, often following endstage of advanced chronic diseases (such as cardiovascular diseases, chronic obstructive pulmonary disease, cancer and dementia). Therefore, many people will go through a period of terminal illness before their death ${ }^{3,4}$.

In Brazil, data from the Brazilian Institute of Geography and Statistics (IBGE) show that 58.1\% of the total deaths occurring in 2015 were among individuals aged $\geq 65$ years (age classified as old in many developed countries) and $66 \%$ in the age group $\geq 60$ years (considered as elderly by the Brazilian Statute of the Elderly) $)^{5}$. In 2013, the main causes of death in Brazil were noncommunicable diseases (72.8\%), specifically the most common were: cerebrovascular diseases, acute myocardial infarction, pneumonia, and diabetes mellitus ${ }^{6,7}$. Faced with this reality, the World Health Organization (WHO) has urged countries to develop specific public policies for palliative care to meet the complex needs of the elderly population ${ }^{4}$. One such recommendation is to encourage health care providers to talk to patients about their preference for place of care and death ${ }^{4}$.

Preferences are defined by personal choices when decisions need to be made about health and treatments, based on experiences, beliefs and values, placing individual autonomy as a central val$\mathrm{ue}^{8,9}$. In this context, one of the most prominent topics is preference for place of death, especially considering the increasing hospitalization of death ${ }^{10,11}$. Studies suggest that people often prefer dying at home (by comparison to dying at an institution, hospital, or even at the home of family and friends), although percentages differ between countries $^{3,12-14}$. A population-based cross-national survey in seven European countries, involving participants aged $\geq 16$ years, showed that a majority of participants in all countries from $51 \%$ in Portugal to $84 \%$ in the Netherlands, would prefer to die at home ${ }^{3,13}$. In this study, the choice of home death became less frequent with age up to 60 years old, but this trend reversed in the older age groups 60-69 and $\geq 70$ (although odds were still lower in these groups than in the reference group: 16$29)^{13,15}$. Although older populations have a higher frequency of death and, consequently, more need for palliative care support, there are few quantitative studies focusing on older people's preferences, especially in low and middle income countries, such as Brazil ${ }^{3}$. Results of some qualitative studies suggest that older people perceive their home as a place of familiarity and comfort, and thus, an ideal place to die. However, some factors (such as not wanting to be a burden on family members, concern about the quality of home care or not having a caregiver) may influence the preference for dying in a place other than home $e^{3,16}$.

In international studies conducted mainly in Japan, Europe and the United States, people's preference for the place of death was not widely respected ${ }^{3,12,13,15,17}$. A recent survey in Japan with older people ( $\geq 65$ years) indicated "home" as the preferred place of death for $68.4 \%$ of men and $52.5 \%$ of women ${ }^{14}$. A study published in 2013 analyzed official 45 reports of places of death of older people showed that $54 \%$ or more of all deaths occurred in hospitals. Japan is shown as the first country in the world where there are more deaths in hospitals ${ }^{17}$. Following Japan, Brazil was considered the second country in the world where there are more deaths in hospitals ${ }^{17}$. In Brazil, $71.6 \%$ of deaths occurred in hospitals in 2015, of which $68 \%$ consisted of people aged $\geq 60^{5}$. Some studies conducted in Brazilian municipalities have demonstrated high death rates in hospital settings ${ }^{18}$. In Araraquara (São Paulo State $)^{19}, 76 \%$ of deaths happened in hospitals between 2006 and 2011. In Londrina (Paraná State ${ }^{18}$, more than $70 \%$ of people died in the hospital from 1996 to 2010. However, we did not find any studies that investigated preference for place of death among Brazilians.

Thus, the objective of this study is to analyze the preferences for place of death among older people ( $\geq 60$ years) living in Belo Horizonte (Brazil) in a scenario of advanced disease with less than one year to live. We also aimed to examine the influence of social and demographic factors on a home death preference versus other locations (palliative care unit, hospital or longterm care facilities).

\section{Methods}

\section{Study design}

This study is quantitative, cross-sectional, descriptive and inferential. The study sample consisted of older people (aged $\geq 60$ ), both men and 
women, living in the city of Belo Horizonte. We considered the population distribution by age and gender according to the 2010 Demographic Census from IBGE when defining our study sample. According to the Census there were 299,177 older people (aged $\geq 60$ ) living in the city of Belo Horizonte. Based on the Krejcie and Morgan ${ }^{20}$ table, a sample size of 400 people would be needed to obtain a representative sample of the older population in Belo Horizonte (confidence level of $95 \%$ and margin of error of $5 \%$ ). To define the sample, we considered distribution by age group (60-69 years; $70-79$ years; $\geq 80$ years) and gender.

\section{Data collection tool}

The questionnaire was developed as part of a Pan-European Commission Project funded by the 7th Framework Programme called "Reflecting the Positive diveRsities of European prIorities for reSearch and Measurement in end of life cAre (PRISMA)" "21,22. The aim of the questionnaire is to analyze the preferences and priorities for end of life among the general population (aged 16 and older) in a situation of serious illness like cancer with less than 1 year. The survey covered England, Flanders (the Dutch speaking part of Belgium), Germany, Italy, the Netherlands, Spain, Portugal and Kenya (Nairobi) ${ }^{12,13}$.

The Portuguese version of the PRISMA European survey questionnaire was culturally adapted to Brazilian Portuguese following the European Organisation for Research and Treatment of Cancer (EORTC)'s translation procedures ${ }^{23}$. A thorough description of the adaptation can be found elsewhere ${ }^{24}$. This study differed from the methodology of the original PRISMA study in Europe in four ways. Firstly, the questionnaire was administered face-to-face instead of over the telephone as recommended by Brazilian palliative care specialists due to the sensitive nature of the topic. Secondly, the scenario of hypothetical advanced illness was broadened to include other relevant conditions in addition to cancer (such as chronic kidney disease, advanced heart failure, dementia, osteoarthritis, and chronic obstructive pulmonary disease). Thirdly, similarly to the English questionnaire but differing from the other European versions, a question about the participant's ethnicity was included in the questionnaire. Finally, we focused on the older population as age and chronic/life-limiting conditions are more common among older age groups.

The Brazilian version of the questionnaire examines preferences and priorities for end-of-life care in a hypothetical situation of serious illness (such as cancer, dementia, Parkinson's disease, chronic obstructive pulmonary disease, heart disease, renal failure or osteoarthritis), with less than one year to live. The questionnaire consists of two parts. The first part includes 10 questions on preferences and priorities at the end of life (approaching access to information; most concerning symptoms and problems; decision-making; dying in preferred place; most important goals). The second part includes sociodemographics questions as well as questions related to experiences with illness, death, dying and general health.

Participants responded where they preferred to die in a scenario of advanced disease by answering the question "In a situation of serious illness with less than one year to live... Where do you think you would prefer to die if circumstances allowed you to choose?". Answer options were: "in your own home", "in the home of a relative or friend", "in a palliative care unit - places with specialized care and beds for people with advanced diseases at the end of life", "in a hospital-but not in a palliative care unit", "in Long-term care facilities" and "somewhere else".

There were challenges when recruiting participants and some potential candidates refuse to participate after learning about the questionnaire topic. Also during questioning, it was observed that not all study participants $(\mathrm{n}=400)$ recognised palliative care units as a place of death. However, an explanation about "palliative care unit" had been made available to interviewers to provide information for the respondents.

\section{Setting}

This study was conducted in the city of Belo Horizonte, Minas Gerais, Brazil, among those aged $\geq 60$ years who corresponded to $8.9 \%$ of the total population in 2000 , increasing to $12.7 \%$ in $2010^{25}$. Following national trends, the majority of people in Belo Horizonte (75.9\%) died in hospitals in $2015^{5}$.

\section{Participants}

We have sampled our population from well-established social programmes developed by Belo Horizonte's City Council focused on assisting community-dwelling older people (providing services and activities such as physical exercises, computing, handicraft, singing lessons, etc). This strategy ensured that the potential par- 
ticipants were living in households as opposed to an institution (similar to the population sampled in the PRISMA surveys).

Participants were sampled from the Reference Centre for Older People (CRPI) which is linked to the Sub-Secretariat of Older People's Rights of Citizenship (SMADC); and 10 older people's community-dwelling groups from the Reference Centre of Social Services (CRAS), managed by the City Council's Sub-Secretariat of Social Services (SMAAS). The SMAAS helped to select ten different groups which covered all nine geographical regions (Barreiro, Centro-Sul, Leste, Nordeste, Noroeste, Norte, Oeste, Pampulha e Venda Nova) in the City of Belo Horizonte and included older people with different levels of social deprivation. The study was approved by the CRPI's coordinator and by the SMAAS Secretary-General.

The study's principal investigator, CRPI and CRAs staff introduced the study to potential participants and discussed its objectives and methodology with those interested in taking part. After answering any queries and clarifying any potential concerns due to the nature of the topic, all who agreed to participate signed a consent form. All questionnaires were administered face to face by the first author who had been in contact with members of the PRISMA Research Team based at King's College London and received guidance about the PRISMA methodology. Data were collected between February and July 2015.

The inclusion criteria were Belo Horizonte residents living at home aged $\geq 60$ years. They also had to have be able to give informed consent; with the advice from CRAS and CRPI's professionals we excluded those who were not able to orient themselves in time and space.

\section{Statistical analysis}

We used descriptive statistics to report participants' demographic, socioeconomic and clinical factors; and their preferences for place of death. Chi-square tests were carried out to investigate associations among age, gender and preference for place of death. We have tested for equality of proportions between two samples in order to compare preferences (home versus another location) under different classes: gender and age groups. We used binomial logistic regression (adopting the "enter" method) to examine factors significantly associated with a preference for home death (one's own or of a relative or friend). There were no missing values in the data set. Home death was considered the dependent variable. We have calculated odds ratio (OR) and $95 \%$ confidence intervals (CI). To establish the theoretical model, an initial regression model defined only by factors with significant crude OR $(\mathrm{p}<0.05)$ was considered. Afterwards, variables with significant more relevant crude OR $(p<0.05)$ were sequentially entered in the model. The final model was found when the next explanatory variables entered in the model did not exhibit significant association $(\mathrm{p}>0.05)$ with the dependent variable. The adjusted odds ratios (AOR) and the 95\% CI were calculated in the final model in order to identify associations of the categorical factors with the dependent variable. Although our analyses focused on the interpretation of the significant factors, we have assessed the goodness of fit of the model using the Hosmer-Lemershow test. All statistical analyzes were performed using IBM SPSS Statistics software, version 23.0 for Windows. Results of statistical tests were deemed statistically significant when $\mathrm{p}<0.05$.

\section{Ethical considerations}

This study was approved by the Ethics Committee of the Department of Social Sciences and Health of the Faculty of Medicine of the University of Porto, Portugal and by the Research Ethics Committee of the Municipal Department of Health of Belo Horizonte (SMSA-BH).

\section{Results}

Four hundred older people living in Belo Horizonte agreed to take part in the study. The median duration of the interviews was 16 minutes (range 6-39 minutes). Interviews took longer among the older age groups (60-69: $15 \mathrm{~min}, 70$ 79: $17 \mathrm{~min}, \geq 80: 19 \mathrm{~min}, \mathrm{p}=0.000)$ and women participants (Female: $17 \mathrm{~min}$, Male: $15 \mathrm{~min}, \mathrm{p}=$ 0.000).

Participants' median age was 69 years (interquartile range 64-76), with the oldest interviewees aged $92(n=2)$. Most participants were retired $(80.8 \%)$, declared themselves as Catholics (66.8\%), coping on present income $(51.7 \%)$ and described their general health as "good" (53.5\%). Regarding experience of illness, $19.0 \%$ of participants received a diagnosis of serious illness in last 5 years (Table 1 ). 
Table 1. Sample characteristics.

\begin{tabular}{|c|c|c|}
\hline Variables & n & $\%$ \\
\hline \multicolumn{3}{|l|}{ Age group } \\
\hline $60-69$ years & 217 & 54.3 \\
\hline 70-79 years & 121 & 30.3 \\
\hline $80+$ & 62 & 15.5 \\
\hline \multicolumn{3}{|l|}{ Gender } \\
\hline Female & 241 & 60.3 \\
\hline Male & 159 & 39.7 \\
\hline \multicolumn{3}{|l|}{ Education } \\
\hline No formal schooling & 30 & 7.5 \\
\hline Up to 4 years & 149 & 37.3 \\
\hline Up to 8 years & 54 & 13.5 \\
\hline Up to 12 years & 122 & 30.5 \\
\hline Higher education & 45 & 11.3 \\
\hline \multicolumn{3}{|l|}{ Marital Status } \\
\hline Single & 61 & 15.3 \\
\hline Married or with a partner & 167 & 41.8 \\
\hline Separated/ Divorced & 50 & 12.5 \\
\hline Widower & 122 & 30.5 \\
\hline \multicolumn{3}{|l|}{ Religion } \\
\hline Roman Catholic & 267 & 66.8 \\
\hline Protestantism/Evangelical & 63 & 15.8 \\
\hline Spiritism/Afro-Brazilian & 37 & 9.3 \\
\hline Other & 11 & 2.8 \\
\hline No religion & 22 & 5.5 \\
\hline \multicolumn{3}{|l|}{ Ethnicity } \\
\hline White & 114 & 28.5 \\
\hline Black & 63 & 15.8 \\
\hline $\begin{array}{l}\text { Brown and other (1: Asian } \\
\text { Brazilian; 1: Indigenous) }\end{array}$ & 223 & 55.8 \\
\hline
\end{tabular}

\section{Preferences for place of death}

Regarding preferences for place of death, $52.2 \%$ preferred home, and $47.8 \%$ opted for some kind of institution (Table 2). Almost half (46.0\%) of participants reported having as much information as they wanted as their most important priority, followed by "choosing who makes decisions about your care" (38.3\%). The least valued aspect was "dying in the place you want" which was chosen as the most important priority by $26.8 \%$ of participants. (Table 3 ).

There were no statistically significant differences in preferences by gender and age, even though males chose home more often (58\% versus $49 \%$ among females; $\mathrm{p}=0.068)$ and those aged 70-79 chose home less often ( $46 \%$ compared to $52 \%$ for $60-69$ and $65 \%$ for $\geq 80, p=0.065)$. A large proportion of men aged 60-69 chose home
Table 1. Sample characteristics.

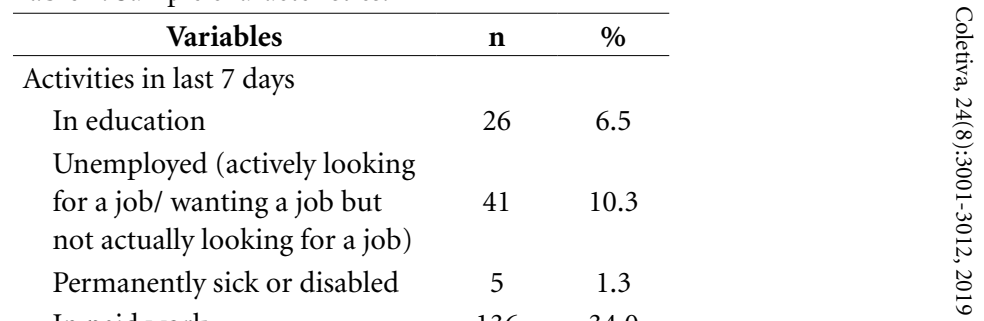

$\begin{array}{lll}\text { Retired } & 323 \quad 80.8\end{array}$

$\begin{array}{lll}\text { Pensioner } & 102 \quad 25.5\end{array}$

Housework, looking after $\quad 34$

$\begin{array}{lll}\text { children or others } & 34 & 8.5 \\ \text { Other } & 38 & 9.5\end{array}$

Financial hardship

Very difficult on present
income

Difficult on present income $\quad 55 \quad 13.8$

$\begin{array}{lll}\text { Coping on present income } & 207 & 51.7\end{array}$

$\begin{array}{lll}\text { Living comfortably on present } & 114 \quad 28.5 \\ \text { income }\end{array}$

Living with: adults

\begin{tabular}{|c|c|c|}
\hline None (myself) & 76 & 19.0 \\
\hline One adult & 153 & 38.3 \\
\hline Two adults & 98 & 24.5 \\
\hline Three adults & 39 & 9.8 \\
\hline Four or more & 34 & 8.5 \\
\hline \multicolumn{3}{|l|}{ iving with: children } \\
\hline None & 351 & 87.8 \\
\hline One Child & 34 & 8.5 \\
\hline Two or more & 15 & 3.8 \\
\hline \multicolumn{3}{|l|}{ Health } \\
\hline Fair & 76 & 19.0 \\
\hline Good & 214 & 53.5 \\
\hline Very good & 110 & 27.5 \\
\hline \multicolumn{3}{|c|}{ xperience of illness, death and dying } \\
\hline $\begin{array}{l}\text { Close relative/friend seriously } \\
\text { ill in last } 5 \text { years }\end{array}$ & 299 & 74.8 \\
\hline $\begin{array}{l}\text { Death of close relative/friend } \\
\text { in last } 5 \text { years }\end{array}$ & 270 & 67.5 \\
\hline $\begin{array}{l}\text { Diagnosed with serious illness } \\
\text { in last } 5 \text { years }\end{array}$ & 76 & 19.0 \\
\hline $\begin{array}{l}\text { Cared for close relative/friend } \\
\text { in last months of life }\end{array}$ & 264 & 66.0 \\
\hline
\end{tabular}

as their preferred place of death (65.4\%), but results were not statistically significant $\left(\chi^{2}=25.23\right.$; $\mathrm{p}=0.090)$. However, men significantly preferred home as place of death (home: $92 / 159=59 \%$, other: $67 / 159=41 \%, \mathrm{p}=0.047)$, as well as people aged $\geq 80$ years (home: $40 / 62=65 \%$, other: $22 / 62$ $=35 \%, \mathrm{p}=0.022)$. 
Table 2. Distribution of preference for place of death by age group and gender.

\begin{tabular}{|c|c|c|c|c|c|c|c|c|}
\hline \multirow{3}{*}{$\begin{array}{c}\text { First } \\
\text { Preference for place of } \\
\text { death }\end{array}$} & \multicolumn{6}{|c|}{ Age group } & \multirow{2}{*}{\multicolumn{2}{|c|}{ Total }} \\
\hline & \multicolumn{2}{|c|}{$60-69$} & \multicolumn{2}{|c|}{$70-79$} & \multicolumn{2}{|c|}{$\geq \mathbf{8 0}$} & & \\
\hline & Male & Female & Male & Female & Male & Female & $\mathbf{n}$ & $\%$ \\
\hline Home $^{1}$ & 59 & 54 & 21 & 35 & 12 & 28 & 209 & 52.2 \\
\hline Palliative care & 17 & 21 & 12 & 13 & 3 & 5 & 71 & 17.8 \\
\hline Hospital & 10 & 36 & 9 & 20 & 4 & 7 & 86 & 21.5 \\
\hline Long-term care facilities & 7 & 13 & 5 & 6 & 0 & 3 & 34 & 8.5 \\
\hline
\end{tabular}

Table 3. Information and decision-making: most important priority of three options.

\begin{tabular}{|c|c|c|}
\hline Variables & $\mathbf{n}$ & $\%$ \\
\hline \multicolumn{3}{|l|}{ Most important in the care available } \\
\hline $\begin{array}{l}\text { Having as much information as } \\
\text { you want }\end{array}$ & 184 & 46.0 \\
\hline $\begin{array}{l}\text { Choosing who makes decisions } \\
\text { about your care }\end{array}$ & 109 & 27.3 \\
\hline Dying in the place you want & 107 & 26.8 \\
\hline \multicolumn{3}{|c|}{ Second most important in the care available } \\
\hline $\begin{array}{l}\text { Having as much information as } \\
\text { you want }\end{array}$ & 135 & 33.8 \\
\hline $\begin{array}{l}\text { Choosing who makes decisions } \\
\text { about your care }\end{array}$ & 153 & 38.3 \\
\hline Dying in the place you want & 112 & 28.0 \\
\hline
\end{tabular}

Three factors (age group, current income and priorities for care: "most important in the care available") showed to be independently associated with the preference for home death $(\mathrm{p}<$ 0.05 , Table 4). Nevertheless, the influence of age group lost significance when other relevant factors were jointly incorporated in the same model. In the final model, five factors were found to be associated with choosing home as the preferred place of death: those living with one child (OR 0.41: 95\%CI: 0.18-0.92; ref: without children); or being in education for up to 4 years (OR 0.42; 95\%CI: $0.20-0.89$; ref: higher education) were less likely to choose home. In contrast, those finding it difficult to live with the present income (OR 3.18; 95\%CI: 1.53-6.62; ref: living comfortably); self-assessed fair overall health (OR 2.07; 95\%CI: 1.06-4.03; ref: very good health) and selecting "choosing who makes decisions about your care" as the care factor that would matter to them the most (OR 2.43; 95\%CI: 1.34-4.40; ref: dying in the preferred place) were more likely to choose home. The binomial logistic regression model showed to be well fitted to the data $(\mathrm{p}=$ 0.404).

\section{Discussion}

To our knowledge, this is the first study to investigate preferences for place of death among older people living in Brazil. Preferences for place of death have been investigated in countries such as the United States, United Kingdom, Canada, Australia, Japan and China ${ }^{3,12-14,26}$. In the European Union population-based survey among seven European countries showed that $51-84 \%$ of participants preferred to die at home along with $51.1 \%$ in Kenya (Nairobi) if they were to die with advanced disease and if circumstances allowed them choose $\mathrm{s}^{12,13}$. Our results show that home (own home or home of a relative or friend) was the preferred place of death for over half of participants $(52.2 \%)$. In contrast, official mortality statistics data from 2015 show that $75.9 \%$ of older people in the municipality of Belo Horizonte died at the hospital ${ }^{5}$. Our results suggest a discrepancy between preferences and actual place of death.

In a scenario of serious illness, with less than one year to live our results indicate that five variables associated with a home death preference. Older people living with one child were less likely to choose home as their preferred place of death (compared with those living without children). The problem of being a burden to others is a factor found in the literature as a source of concern at the end of life ${ }^{16,27-29}$. Older people do not wish to be a burden on their family, especially when living with children, who also have their family to care for. However, there was no significant association between living with two or more children and a home preference. Furthermore, we found that participants who lived with more than one adult at home were not more likely to choose 
Table 4. Influence of factors on preference for home death.

\begin{tabular}{|c|c|c|c|c|}
\hline Variables & OR $(95 \%-C I)$ & $\begin{array}{l}\text { p-value } \\
\text { OR }\end{array}$ & AOR $(95 \%-C I)$ & $\begin{array}{l}\text { p-value } \\
\text { AOR }\end{array}$ \\
\hline \multicolumn{5}{|l|}{ Age group (ref: $80+$ ) } \\
\hline $60-69$ & $1.67(0.93-3.00)$ & 0.084 & NS & 0.272 \\
\hline $70-79$ & $2.11(1.12-3.97)$ & 0.020 & NS & 0.072 \\
\hline \multicolumn{5}{|l|}{ Gender (ref. Man) } \\
\hline Woman & $1.46(0.97-2.18)$ & 0.068 & NS & 0.186 \\
\hline \multicolumn{5}{|l|}{$\begin{array}{l}\text { How many adults do you live with? (ref: none/ } \\
\text { myself) }\end{array}$} \\
\hline 1 adult & $0.76(0.44-1.32)$ & 0.327 & & \\
\hline 2 adults & $0.84(0.46-1.53)$ & 0.567 & & \\
\hline 3 adults & $1.52(0.69-3.33)$ & 0.298 & & \\
\hline 4 or more & $0.66(0.29-1.51)$ & 0.327 & & \\
\hline \multicolumn{5}{|l|}{ How many children do you live with? (ref: none) } \\
\hline 1 child & $0.50(0.24-1.06)$ & 0.072 & $0.41(0.18-0.92)$ & 0.031 \\
\hline 2 or more & $1.58(0.55-4.53)$ & 0.396 & $1.70(0.55-5.22)$ & 0.357 \\
\hline \multicolumn{5}{|l|}{ Marital status (ref: single) } \\
\hline Married & $0.77(0.43-1.39)$ & 0.385 & & \\
\hline Married but separated & $1.81(0.49-6.66)$ & 0.370 & & \\
\hline Divorced & $0.82(0.36-1.84)$ & 0.622 & & \\
\hline Widower & $0.74(0.40-1.38)$ & 0.347 & & \\
\hline In a stable relationship & $1.51(0.33-6.89)$ & 0.594 & & \\
\hline \multicolumn{5}{|l|}{ Religion (ref: no religion) } \\
\hline Roman Catholic & $0.70(0.29-1.68)$ & 0.425 & & \\
\hline Evangelical & $0.98(0.37-2.59)$ & 0.963 & & \\
\hline Spiritist & $0.64(0.22-1.84)$ & 0.402 & & \\
\hline Other & $1.46(0.33-6.46)$ & 0.619 & & \\
\hline \multicolumn{5}{|l|}{ Professional activity in the last 7 days } \\
\hline Student (ref. No) & $2.17(0.94-5.00)$ & 0.068 & NS & 0.083 \\
\hline Unemployed looking for a job (ref. No) & $1.24(0.47-3.29)$ & 0.662 & & \\
\hline Unemployed not looking for a job (ref. No) & $1.57(0.68-3.63)$ & 0.288 & & \\
\hline Permanently sick or disabled (ref. No) & $0.73(0.12-4.40)$ & 0.728 & & \\
\hline Paid work (ref. No) & $0.84(0.55-1.27)$ & 0.405 & & \\
\hline Retired (ref. No) & $1.28(0.77-2.11)$ & 0.339 & & \\
\hline Pensioner (ref. No) & $1.25(0.80-1.97)$ & 0.324 & & \\
\hline Housework (ref. No) & $0.75(0.37-1.53)$ & 0.424 & & \\
\hline Other & $0.77(0.40-1.53)$ & 0.465 & & \\
\hline \multicolumn{5}{|l|}{$\begin{array}{l}\text { Financial Hardship (ref: allows to live } \\
\text { comfortably) }\end{array}$} \\
\hline Very difficult & $1.75(0.72-4.24)$ & 0.217 & $1.62(0.60-4.36)$ & 0.342 \\
\hline Difficult & $2.59(1.33-5.03)$ & 0.005 & $3.18(1.53-6.62)$ & 0.002 \\
\hline Coping & $1.30(0.82-2.07)$ & 0.262 & $1.30(0.78-2.16)$ & 0.311 \\
\hline \multicolumn{5}{|l|}{ Health (ref: very good) } \\
\hline Fair & $1.68(0.93-3.03)$ & 0.089 & $2.07(1.06-4.03)$ & 0.025 \\
\hline Good & $0.92(0.58-1.47)$ & 0.736 & $1.00(0.61-1.64)$ & 0.991 \\
\hline \multicolumn{5}{|l|}{ Experience with illness, dying and death } \\
\hline $\begin{array}{l}\text { Family member or friend diagnosed with } \\
\text { serious illness (ref: No) }\end{array}$ & $0.96(0.61-1.51)$ & 0.859 & NS & 0.459 \\
\hline $\begin{array}{l}\text { Closely experienced death of a family member/ } \\
\text { friend (ref. No) }\end{array}$ & $1.00(0.66-1.53)$ & 0.987 & & \\
\hline Received diagnosis of severe illness (ref. No) & $0.71(0.43-1.17)$ & 0.178 & & \\
\hline $\begin{array}{l}\text { Involved in supporting close relative/friend in } \\
\text { last months of life (ref. No) }\end{array}$ & $0.95(0.63-1.44)$ & 0.823 & & \\
\hline
\end{tabular}


Table 4. Influence of factors on preference for home death.

\begin{tabular}{|c|c|c|c|c|}
\hline Variables & OR $(95 \%-C I)$ & $\begin{array}{c}\text { p-value } \\
\text { OR }\end{array}$ & AOR $(95 \%-C I)$ & $\begin{array}{c}\text { p-value } \\
\text { AOR }\end{array}$ \\
\hline \multicolumn{5}{|l|}{ Education (ref: higher education or more) } \\
\hline No formal schooling & $0.84(0.33-2.12)$ & 0.704 & $0.38(0.13-1.10)$ & 0.074 \\
\hline Up to 4 years & $0.58(0.30-1.14)$ & 0.114 & $0.42(0.20-0.89)$ & 0.022 \\
\hline Up to 8 years & $0.59(0.26-1.30)$ & 0.188 & $0.55(0.23-1.30)$ & 0.173 \\
\hline Up to 11 years & $0.68(0.34-1.36)$ & 0.281 & $0.73(0.35-1.52)$ & 0.398 \\
\hline \multicolumn{5}{|l|}{ Ethnicity (ref: white) } \\
\hline Black & $1.83(0.98-3.42)$ & 0.056 & NS & 0.065 \\
\hline Brown (1 Asian Brazilian and 1 indigenous) & $1.27(0.80-2.00)$ & 0.306 & NS & 0.233 \\
\hline \multicolumn{5}{|l|}{$\begin{array}{l}\text { Most important in the care available (ref: dying in } \\
\text { the place you want) }\end{array}$} \\
\hline Having as much information as you want & $1.28(0.79-2.08)$ & 0.309 & $1.34(0.79-2.25)$ & 0.277 \\
\hline Choosing who makes decisions about your care & $1.75(1.02-3.00)$ & 0.041 & $2.43(1.34-4.40)$ & 0.004 \\
\hline \multicolumn{5}{|l|}{$\begin{array}{l}\text { Second most important (ref: dying in the place } \\
\text { you want) }\end{array}$} \\
\hline Having as much information as you want & $0.83(0.50-1.38)$ & 0.479 & & \\
\hline Choosing who makes decisions about your care & $1.12(0.69-1.82)$ & 0.656 & & \\
\hline
\end{tabular}

home as their preferred place of death. Perhaps this is because larger families often have more caregivers available.

Older people with up to 4 years of education were less likely to prefer a home death than those who had higher education. One possible explanation is that people with different levels of education engaged in planning their deaths in different ways ${ }^{30,31}$. Perhaps autonomy represents a greater value for those with higher education and the house is perceived as a place of greater empowerment ${ }^{31}$. However, there are few studies that investigates the associations between preference for home death and level of education ${ }^{32}$. Previous research in Ibiza $^{33}$ and China ${ }^{34}$ showed that low educational attainment is associated with a greater preference for death at home and those with higher attainment prefer to die in institutions ${ }^{32}$. Our results point to a contrary association. Cultural differences between countries may explain this difference. Therefore, further studies are needed to better understand these associations.

Furthermore, older people who described their fair overall health were more likely to choose home as their preferred place of death (compared to those who evaluated their health as very good). It should be noted that no participant evaluated his/her general health as bad or very bad. There are few studies that associate self-rated health and preference of the place of death ${ }^{14}$. A population-Based Survey in Hong Kong found an associated poor self-rated health with lower preference to die at home ${ }^{26}$. A study about preferences for the place of death among Japanese older people, found that good self-rated health was significantly associated with a home death preference ${ }^{14}$. Those who evaluated their self-rated health as good may have had an adequate motor function and quality of life, and this may decrease future concern about the need for a medical institution ${ }^{14}$.

Older people finding it difficult to live on present income were more likely to prefer home, compared with those living comfortably on present income. In Brazil, delays in medical assistance, lack of doctors and hospital beds are common in public hospitals ${ }^{35-37}$. Participants who reported difficulties living on present income are likely to be users of these services. In this sense, older people may prefer to die at home for fear of not receiving adequate end of life care in public hospitals.

Finally, older people who stated that "choosing who makes decisions about your care" was the most important care priority were more likely to choose a home death than those who choose "dying in the place you want". It is possible that older people who stay at home feel more empowered and able to make decisions at home than at an institution.

By using the PRISMA questionnaire and adopting a similar methodology, we found that the proportion of Brazilians choosing home as their preferred place of death is similar to the one 
reported in Portugal ${ }^{15}$ but lower than in other European countries ${ }^{13}$. This happened even though the investigated population in Brazil is older than the one investigated in Europe, where the odds of preferring a home death actually increased for those aged $\geq 60$. This may have several social, cultural and/or family reasons. It is possibly related to the limited availability of public domiciliary services and the high cost of private services, in addition to unfavorable socioeconomic circumstances among a large part of the Brazilian older population. The poor availability of such services could also help to explain the comparatively higher proportion of participants choosing hospital (over a fifth in Brazil compared to less than 7.0\% in Europe) and long-term care facilities (over $8.0 \%$ compared to $2.2 \%$ in Europe) as their preferred place of death. Nonetheless, it is worth noting that participants may also have had a genuine wish to die in hospital. Other possible explanations for the lower proportion could be concerns about being a burden to family and friends if staying at home $e^{27,28}$. Nonetheless, despite the lower proportion of home preferences compared to some European countries, our results indicate that the home death preferences in Brazil are in line with international evidence reporting that most people would prefer to die at home.

The Brazilian questionnaire described a hypothetical scenario of a serious illness, without giving cancer as the only example (as in the original PRISMA survey). This allowed participants to imagine a wide range of serious conditions other than cancer (which were not possible to be recorded for the analysis). Evidence suggests that a home death preference is less frequent amongst those with a non-malignant condition; whose complex needs may not always be met at home ${ }^{38}$.

We have focused on investigating preferences for home death and factors associated with this preference due to the international evidence showing that the majority of the population would prefer to die at home $\mathrm{e}^{3,12-14}$. Nonetheless, it is worth noting that not everyone might wish to die at home and people's preferences should be respected. Over $20.0 \%$ of the participants chose a hospital, while almost a fifth chose a palliative care unit and $8.5 \%$ chose long-term care facilities. It is therefore urgent to expand the provision of palliative care services in these settings. Furthermore, it is crucial to implement palliative care not only at home, but also in other care settings. In Belo Horizonte, following national patterns, the majority of palliative care is offered in hospitals ${ }^{39}$. Hence, there is need to expand the provision of pallia- tive care elsewhere. It is also essential to inform the population about palliative care, and enhance discussions about death and dying. The lead author noticed that speaking of death and dying was considered a taboo and potential barrier to participation. Broad at al. ${ }^{17}$ highlighted that death is still considered a taboo in several countries, an unpleasant topic which could bring bad luck and recommends. However there is an increasing emphasis on asking older people to discuss options for end-of-life care and to plan advanced care ${ }^{17}$.

Respecting patient autonomy is an ethical principle in health care provision, including palliative care. Furthermore, there is an increased recognition of the importance of offering information and supporting preferences from patients and their families in order to plan for appropriate care provision ${ }^{14}$. It is paramount to implement public policies which allow for patient preferences to be respected and for resources to be made available so they can be met whenever appropriate. International policies such as the UK's "End of Life Strategy" have shown that it possible to reduce the proportion of hospital deaths as well as increasing the proportion of deaths at home, thereby respecting the preferences of terminal patients ${ }^{40,41}$. Effective strategies to allow for preferences to be met include the provision of information, discussing preferences in advance with patients and families and providing palliative care in different settings ${ }^{41}$.

In this study, we investigated the preferences and priorities at the end of life among the elderly population of Belo Horizonte regarding the place of death. It was possible to obtain evidence to help to direct public health efforts and policies, and this has potential to avoid wasting resources on unnecessary treatments.

\section{Limitations and research perspectives}

Although the research was carried out in all regions of the city of Belo Horizonte with older people, participants were active people who cared for their health. Thus, the recruitment process excluded people with more functional dependence and fragility. Future studies should include group comparisons, considering the current health status of older people and involving participants with greater functional dependencies. The study considers a hypothetical situation of serious illness; longitudinal studies are recommended to analyze how preferences for place of death are organized when faced with a serious illness with less than one year to live. 


\section{Conclusion}

Results indicate that older people's preferences for place of death in the city of Belo Horizonte are in line with the international evidence, which shows that most people prefer to die at home. In several countries, public policies in palliative care have been made based on national studies on population preferences. In Brazil, policies for older people in the final stages of life are scarce and we have not found previous studies on preferences for place of death. Therefore, we recommend the development of a national Palliative Care Program in Brazil. It is fundamental to create specialized teams, in different care settings, (instead of prioritizing hospital services), in order to respect end-of-life preferences. In this sense, this study may contribute to the development of higher quality palliative care services in Brazil.

\section{Collaborations}

All authors were involved in study design, survey development, cultural adaptation of the survey, data analysis, and took part in the interpretation of findings and manuscript preparation. $\mathrm{R}$ Jorge designed the study, administered the questionnaire, analyzed the results and wrote the manuscript. N Calanzani interpreted the data, revised and approved the manuscript. A Freitas analyzed and interpreted the data, prepared the article and approved the version to be published. $\mathrm{R}$ Nunes was involved in writing and reviewing the manuscript and approved the version to be published. L Sousa participated in the design of the study, analysis of results and writing of the manuscript. 


\section{Acknowledgments}

PRISMA was funded by the European Commission's Seventh Framework Programme (contract number: Health-F2-2008-201655) with the overall aim to co-ordinate high-quality international research into end-of-life cancer care. PRISMA aimed to provide evidence and guidance on best practice to ensure that research can measure and improve outcomes for patients and families. PRISMA activities aimed to reflect the preferences and cultural diversities of citizens, the clinical priorities of clinicians, and appropriately measure multidimensional outcomes across settings where end-of-life care is delivered. Principal Investigator: Richard Harding. Scientific Director: Irene J Higginson. PRISMA members: Gwenda Albers, Barbara Antunes, Ana Barros Pinto, Claudia Bausewein, Dorothee Bechinger-English, Hamid Benalia, Emma Bennett, Lucy Bradley, Lucas Ceulemans, Barbara A Daveson, Luc Deliens, Noël Derycke, Martine de Vlieger, Let Dillen, Julia Downing, Michael Echteld, Natalie Evans, Dagny Faksvåg Haugen, Silvia Finetti, Nancy Gikaara, Barbara Gomes, Marjolein Gysels, Sue Hall, Richard Harding, Irene J Higginson, Stein Kaasa, Jonathan Koffman, Pedro Lopes Ferreira, Arantza Meñaca, Johan Menten, Natalia Monteiro Calanzani, Fliss Murtagh, Bregje Onwuteaka-Philipsen, Roeline Pasman, Francesca Pettenati, Robert Pool, Richard A. Powell, Miel Ribbe, Katrin Sigurdardottir, Steffen Simon, Franco Toscani, Bart Van den Eynden, Paul Vanden Berghe and Trudie van Iersel.

RJ was supported by Coordination for the Improvement of Higher Education Personnel (CAPES). AF was supported by Fundação para a Ciência e a Tecnologia (FCT), within project UID/ MAT/04106/2019 (CIDMA). LS was supported by National Funds through FCT - Fundação para a Ciência e a Tecnologia within CINTESIS, R\&D Unit (reference UID/IC/4255/2019).

\section{References}

1. Tannure MC, Alves M, Sena RR, Chianca TCM. Perfil epidemiologico da população idosa de Belo Horizonte, MG, Brasil. Rev Bras Enferm 2010; 63(5):817-822.

2. Chaimowicz F, Barcelos EM, Madureira MDS, Ribeiro MTF. Saúde Do Idoso. 2a ed. Belo Horizonte: NESCON UFMG; 2013.

3. Gomes B, Calanzani N, Gysels M, Hall S, Higginson IJ. Heterogeneity and changes in preferences for dying at home: a systematic review. BMC Palliat Care 2013; 12(1):7.

4. Hall S, Petkova H, Tsouros AD, Constantini M, Higginson IJ, editors. Palliative care for older people: better practices. Copenhagen: World Health Organization (WHO), Regional Office for Europe; 2011.

5. Instituto Brasileiro de Geografia e Estatística (IBGE). Estatísticas de Registro Civil. Rio de Janeiro: IBGE; 2015. v. 42.

6. Brasil. Ministério da Saúde (MS). Saúde Brasil 2014: Uma análise da situação de saúde e causas externas. Brasília: MS; 2015.

7. Mássimo EAL, Souza HNF, Freitas MIF. Doenças crônicas não transmissíveis, risco e promoção da saúde: construções sociais de participantes do Vigitel. Cien Saude Colet 2015; 20(3):679-688.

8. Abreu CBB, Fortes PAC. Questões éticas referentes às preferências do paciente em cuidados paliativos. Rev Bioét 2014; 22(2):299-308.

9. Jonsen AR, Siegler M, Winslade WJ. Clinical Ethics: A Practical Approach to Ethical Decisions in Clinical Medicine. New York: McGraw-Hill Medical; 2010.

10. Gomes B, Higginson IJ. Where people die (19742030): past trends, future projections and implications for care. Palliat Med 2008; 22(1):33-41.

11. Higginson IJ, Sarmento VP, Calanzani N, Benalia H, Gomes B. Dying at home - is it better: A narrative appraisal of the state of the science. Palliat Med 2013; 27(10):918-924.

12. Downing J, Gomes B, Gikaara N, Munene G, Daveson BA, Powell RA, Mwangi-Powell FN, Higginson IJ, Harding R; Project PRISMA. Public preferences and priorities for end-of-life care in Kenya: a population-based street survey. BMC Palliat Care 2014; 13(1):4.

13. Gomes B, Higginson IJ, Calanzani N, Cohen J, Deliens L, Daveson BA, Bechinger-English D, Bausewein C, Ferreira PL, Toscani F, Meñaca A, Gysels M, Ceulemans L, Simon ST, Pasman HR, Albers G, Hall S, Murtagh FE, Haugen DF, Downing J, Koffman J, Pettenati F, Finetti S, Antunes B, Harding R; PRISMA. Preferences for place of death if faced with advanced cancer: A population survey in England, Flanders, Germany, Italy, The Netherlands, Portugal and Spain. Ann Oncol 2012; 23(8):2006-2015.

14. Ohmachi I, Arima K, Abe Y, Nishimura T, Goto H, Aoyagi K. Factors influencing the preferred place of death in community-dwelling elderly people in Japan. Int J Gerontol 2015; 9(1):24-28.

15. Gomes B, Sarmento VP, Ferreira PL, Higginson IJ. Estudo Epidemiológico dos Locais de Morte em Portugal em 2010 e Comparação com as Preferências da População Portuguesa. Acta Med Port 2013; 4(4):327334. 
16. Gott M, Seymour J, Bellamy G, Clark D, Ahmedzai S. Older people's views about home as a place of care at the end of life. Palliat Med 2004; 18(5):460-467.

17. Broad JB, Gott M, Kim H, Boyd M, Chen H, Connolly MJ. Where do people die? An international comparison of the percentage of deaths occurring in hospital and residential aged care settings in 45 populations, using published and available statistics. Int J Public Health 2013; 58(2):257-267.

18. Marcucci FCI, Cabrera MAS. Morte no hospital e no domicílio: influências populacionais e das políticas de saúde em Londrina, Paraná, Brasil (1996 a 2010). Cien Saude Colet 2015; 20(3):833-840.

19. Telarolli Júnior R, Loffredo LCM. Mortalidade de idosos em município do Sudeste brasileiro de 2006 a 2011. Cien Saude Colet 2014; 19(3):975-984.

20. Krejcie RV, Morgan DW. Determining Sample Size for Research Activities. Educ Psychol Meas 1970; 30(3):607-610.

21. Calanzani N, Moens K, Cohen J, Higginson IJ, Harding R, Deliens L, Toscani F, Ferreira PL, Bausewein C, Daveson BA, Gysels M, Ceulemans L, Gomes B; Project PRISMA. Choosing care homes as the least preferred place to die: a cross-national survey of public preferences in seven European countries. BMC Palliat Care 2014; 13(1):48.

22. Lopes Ferreira P, Antunes B, Barros Pinto A, Gomes B. Cuidados de fim de vida: Portugal no projeto europeu PRISMA. Rev Port Saude Publica 2012; 30(1):62-70.

23. Cull A, Sprangers M, Bjordal K, Aaronson N, West K, Bottomley A. EORTC Quality of Life Group Translation Procedure. $2^{\text {nd }}$ ed. Brussels: EORTC Quality of Life Group; 2002.

24. Jorge R, Sousa L, Nunes R. Preferências e prioridades para os cuidados de fim de vida de pessoas idosas: adaptação cultural para o Brasil. Geriatr Gerontol Aging 2016; 10(2):101-111.

25. Instituto Brasileiro de Geografia e Estatística (IBGE). Sinopse dos resultados do censo do IBGE 2010. Rio de Janeiro: IBGE; 2010.

26. Chung RYN, Wong ELY, Kiang N, et al. Knowledge, Attitudes, and Preferences of Advance Decisions, Endof-Life Care, and Place of Care and Death in Hong Kong. A Population-Based Telephone Survey of 1067 Adults. J Am Med Dir Assoc 2017; 18(4):367.e19-367. e27.

27. Bausewein C, Calanzani N, Daveson BA, et al. "Burden to others" as a public concern in advanced cancer: a comparative survey in seven European countries. BMC Cancer 2013; 13(105):11.

28. Wilson KG, Curran D, McPherson CJ. A Burden to Others: A Common Source of Distress for the Terminally Ill. Cogn Behav Ther 2005; 34(2):115-123.

29. Akechi T, Miyashita M, Morita T, et al. Good Death in Elderly Adults with Cancer in Japan Based on Perspectives of the General Population. J Am Geriatr Soc 2012; 60(2):271-276.
30. Seale C, Addington-Hall J, McCarthy M. Awareness of Dying: Prevalence, Causes and Consequences. Soc Sci Med 1997; 45(3):477-484.

31. Cohen J, Bilsen J, Hooft P, Deboosere P, Wal G van der, Deliens L. Dying at home or in an institution. Using death certificates to explore the factors associated with place of death. Health Policy 2006; 78(2-3):319-329.

32. Schou-Andersen M, Ullersted MP, Jensen AB, Neergaard MA. Factors associated with preference for dying at home among terminally ill patients with cancer. Scand J Caring Sci 2016; 30(3):466-476.

33. Cortés Pradilla H, Correa Ospina OL, Alonso-Babarro A. Preferencia del lugar de muerte y factores relacionados en personas mayores de la isla mediterránea de Ibiza. Rev Colomb Anestesiol 2011; 39(2):174-188.

34. Gu X, Cheng W, Cheng M, Liu M, Zhang Z. The Preference of Place of Death and its Predictors Among Terminally Ill Patients With Cancer and Their Caregivers in China. Am J Hosp Palliat Care. 2015; 32(8):835-840.

35. Adas S, Moimaz S, Saliba O. Sobre o serviço público de saúde. Physis Rev Saúde Coletiva 2010; 20(4):14191440.

36. Almeida ND. A saúde no Brasil, impasses e desafios enfrentados pelo Sistema Único de Saúde - SUS. Rev Psicol e Saúde 2013; 5(1):1-9.

37. Instituto de Pesquisa Econômica Aplicada (IPEA). Sistema de Indicadores de Percepção Social (SIPS). Brasília: IPEA; 2011.

38. Billingham MJ, Billingham S-J. Congruence between preferred and actual place of death according to the presence of malignant or non-malignant disease: a systematic review and meta-analysis. BMJ Support Palliat Care 2013; 3(2):144-154.

39. Academia Nacional de Palliative care (ANCP). Onde existem cuidados paliativos. [Internet] [acessado 2017 Ago 6]. Disponível em: http://paliativo.org.br/ancp/ onde-existem/.

40. Gomes B, Sarmento VP, Ferreita PL, Higginson IJ. Preferências e locais de morte em regiões de Portugal em 2010. London: King's College London; 2013.

41. London. Department of Health. End of life care strategy: promoting high quality care for all adults at the end of life. London: Department of Health; 2008.

Artigo apresentado em 06/08/2017

Aprovado em 14/11/2017

Versão final apresentada em 16/11/2017 